\title{
Problems and Prospects of Battery Dealers
}

\author{
P. N. Raghunathan* \\ Assistant Professor, Department of Business Administration, Government Arts College, Coimbatore, India; \\ pnragu@yahoo.com
}

\begin{abstract}
The industrial batteries consumption is going up every year with the economy booming. This in turn will create more opportunities and demand for the batteries in the sectors such as telecom towers, railway usage, automobiles, power sector and household for UPS inverters. With the country short of power in several pockets, usage of inverters too, has gone up significantly, and this is not going to come down in the near future. Hence, studying about the battery dealers' opinion on problems and prospects of battery business in the study area is quite significant as it will expose the difficulties confronted by them and scope for the prospects of their business. For the purpose of the study both primary and secondary data were employed. Convenience sampling method was adopted to collect the primary data from 200 battery dealers of various brands from the three districts namely Coimbatore, Erode and Tirupur. Field survey method was employed to collect first hand information through a well-structured questionnaire. Secondary data was also collected for the study from books, journals and news papers. It is clear from the study that the present battery dealership business performance is good. However, companies have to create certain policies which reduce the stringent formalities in the business to encourage the dealers and promote the business.
\end{abstract}

Keywords: Battery Dealers, Dealers' Problems, Service Quality

\section{Introduction}

In India, there are about twelve major automotive manufacturers, and all of them are growing rapidly, and also looking at making India their home for exports. This would further enhance the overall market base and growth opportunity. The industrial batteries consumption is going up every year with the economy booming. This in turn will create more opportunities and demand for the batteries in the sectors such as telecom towers, railway usage, automobiles, power sector and household for UPS inverters. With the country short of power in several pockets, usage of inverters too, has gone up significantly, and this is not going to come down in the near future.

Given the market potential, for the first time an International Battery Fair is being hosted in India, which is normally hosted in the U.S. and Europe. This shows how the global market is viewing India and its business prospects. More demand has emerged for Indian batteries in the international market. Hence, the manufacturers are also gearing up to meet the demand. Marketing Channel intermediaries are of different types like marketer, broker, franchisee, sole-selling agent, and retailer and so on. These marketing intermediaries differ significantly in their roles, capabilities, territories, level and size of operations, cost of operations, remunerations and amenability for control by the principal. Among those, dealers form the bottom of the hierarchy, working under wholesalers/stockiest/semiwholesalers as the case may be. The dealers are sometimes referred to as retailers or authorized representatives. They operate in a relatively smaller territory or at a specific location; they do not normally perform stock-holding and sub-distribution functions. Under this scenario, studying about the battery dealers' opinion on problems

* Author for correspondence 
and prospects of battery business in the study area is quite significant as it will expose the difficulties confronted by them and scope for the prospects of their business.

\section{Review of Literature}

A review of previous studies enabled to identify the research gap and to establish the objectives of the present study. Raymond Obdianela M., [1] disclosed that logistical capacity should be enhanced to replace the defective batteries with new ones and however majority of the dealers were satisfied with the services of the company. Rahim S., [2] asserted that car batteries are heavy and hence expensive to transport. Hussain N., Bhatti W.A. and Jilani A., [3] assessed the after-sales service provided for Atlas Battery in Pakistan employing SERVQUAL technique. Tim Steinweg [4] exposed that production of car battery is not labour intensive. Sachin Farfad [5] conformed that the dealers of Ameron and Exide batteries used counter sales process to sell and provided free checking service to attract customers.

\section{Objectives of the Study}

- To know the opinion of the battery dealers in the study area.

- $\quad$ To bring out the problems faced by the battery dealers and to suggest better ways to overcome it.

\section{Methodology}

For the purpose of the study both primary and secondary data were employed. Convenience sampling method was adopted to collect the primary data from 200 battery dealers of various brands from the three districts namely Coimbatore, Erode and Tirupur. Field survey method was employed to collect first hand information through a well-structured questionnaire. Secondary data was also collected for the study from books, journals and news papers.

\subsection{Tools and Analysis}

The collected data were classified into suitable tabular forms for analysis and interpretation. Simple statistical tools like simple percentage method, and Henry Garrett ranking method were used for analyzing the collected data.

\section{Analysis and Interpretation}

Table 1. Duration of doing battery business

\begin{tabular}{|c|c|c|}
\hline Duration & No. of Respondents & Percentage \\
\hline$<2$ yr & 57 & 29 \\
\hline 2 to 5 yrs & 82 & 41 \\
\hline$>5$ yrs & 61 & 31 \\
\hline Total & $\mathbf{2 0 0}$ & $\mathbf{1 0 0}$ \\
\hline
\end{tabular}

Table 1 highlights that 41 per cent of the respondents were doing the battery business for a period from 2 to 5 years. It is followed by 31 percent of the respondents doing the battery business for a period of more than 5 years. 29 percent of the respondents were doing the business for a period of less than 2 years. The same is exhibited in Figure 1.

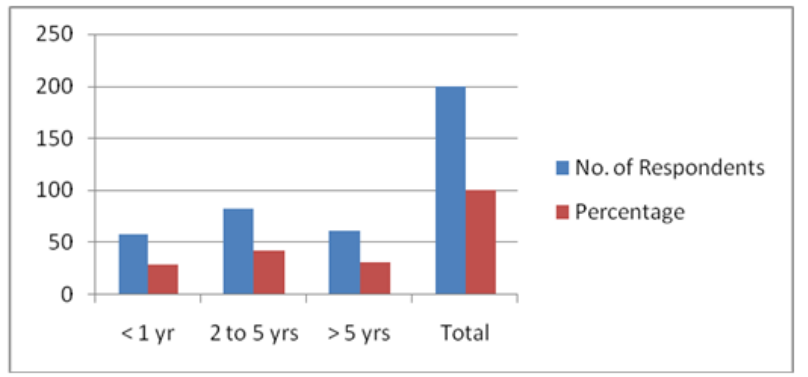

Figure 1. Duration of doing battery business.

Table 2. Factors influencing to do the battery business

\begin{tabular}{|c|c|c|}
\hline Factors & No. of Respondents & Percentage \\
\hline Own Decision & 74 & 37 \\
\hline Friends \& Relatives & 61 & 31 \\
\hline Family Members & 37 & 19 \\
\hline $\begin{array}{c}\text { Based on the Business } \\
\text { opportunity }\end{array}$ & 28 & 14 \\
\hline Total & $\mathbf{2 0 0}$ & $\mathbf{1 0 0}$ \\
\hline
\end{tabular}

From Table 2, it is inferred that 37 percent of the respondents had taken their own decision to engage in the battery business. It is followed by 31 percent of the respondents who were influenced by their friends and relatives. 19 percent of the respondents were influenced by their family members. 14 percent of the respondents had taken the decision due to the business opportunity. 
Table 3. Source of information about the dealership opportunity

\begin{tabular}{|c|c|c|}
\hline Information Source & No. of Respondents & Percentage \\
\hline Advertisement & 109 & 55 \\
\hline Relatives \& Friends & 64 & 32 \\
\hline Company Executives & 27 & 14 \\
\hline Total & $\mathbf{2 0 0}$ & $\mathbf{1 0 0}$ \\
\hline
\end{tabular}

From Table 3, it is found that 55 percent of the respondents have come to know about the battery dealership opportunity through advertisements. It is followed by 32 percent of the respondents knowing it through their relatives and friends and remaining 14 percent of them have come to know through the battery company executives.

Table 4. Opinion on present business performance

\begin{tabular}{|c|c|c|}
\hline Movement & No. of Respondents & Percentage \\
\hline Very Good & 28 & 14 \\
\hline Good & 109 & 54.5 \\
\hline Not Bad & 58 & 29 \\
\hline Slow & 5 & 5.5 \\
\hline Total & 200 & 100 \\
\hline
\end{tabular}

Table 4 depicts that 54.5 percent of the respondents were of the opinion that their present business performance is good. It is followed by 29 percent of the respondents who opined that their business is not bad. 14 percent of the respondents were of the opinion that their business performance is very good. A meager percent of the respondents alone were of the opinion that their business performance is slow.

Table 5. Average Sales per Month

\begin{tabular}{|c|c|c|}
\hline Average Sales & No. of Respondents & Percentage \\
\hline < Rs. 30000 & 37 & 19 \\
\hline Rs. 30,000 to 50,000/- & 104 & 52 \\
\hline > Rs. 50,000/- & 59 & 30 \\
\hline Total & $\mathbf{2 0 0}$ & $\mathbf{1 0 0}$ \\
\hline
\end{tabular}

It is observed from Table 5 that 52 percent of the respondents' average sales in a month was between Rs. 30000 and Rs.50,000/-. It is followed by 30 percent of the respondents' average monthly sales of above 50,000/-. 19 percent of the respondents' average monthly sales were less than Rs.30,000/-.

Table 6. Reasons for the fluctuation in business performance

\begin{tabular}{|c|c|c|}
\hline Reasons for the fluctuation & $\begin{array}{c}\text { No. of } \\
\text { Respondents }\end{array}$ & Percentage \\
\hline More Customer expectations & 18 & 9 \\
\hline Stiff Competition & 82 & 41 \\
\hline Market Demand & 61 & 30.5 \\
\hline Less Advertisement & 39 & 19.5 \\
\hline Total & $\mathbf{2 0 0}$ & $\mathbf{1 0 0}$ \\
\hline
\end{tabular}

Table 6 highlights that 41 percent of the respondents were of the opinion that the stiff competition was the reason for fluctuation in their business performance. It is followed by 30.5 percent of the respondents expressing that the market demand was the reason for business fluctuations. 19.5 per cent of the respondents opined that less advertisement was the reason for business fluctuations. A meager percent of the respondents opined that customer expectation was the reason for the business fluctuations. The same is exhibited in Figure 2.

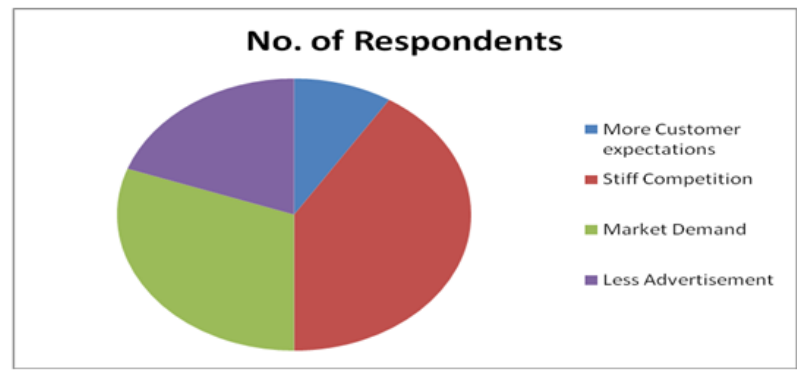

Figure 2. Reasons for the fluctuation in business performance.

Table 7. Type of batteries moving fast in the market as per respondents' claim

\begin{tabular}{|c|c|c|}
\hline Battery & No. of Respondents & Percentage \\
\hline Two Wheelers & 48 & 24 \\
\hline Three Wheelers & 38 & 19 \\
\hline Four Wheelers & 92 & 46 \\
\hline Tubular Battery & 22 & 11 \\
\hline Total & $\mathbf{2 0 0}$ & $\mathbf{1 0 0}$ \\
\hline
\end{tabular}


It can be found from Table 7 that 46 percent of the respondents had claimed that four wheeler batteries only were moving fast in the market, followed by 24 percent of the respondents expressing that two wheeler batteries only were moving fast. 19 percent of the respondents had opined that three wheeler batteries only were moving fast, while 11 percent of the respondents had expressed that tubular batteries only were moving fast in the market. The same is exhibited in Figure 3.
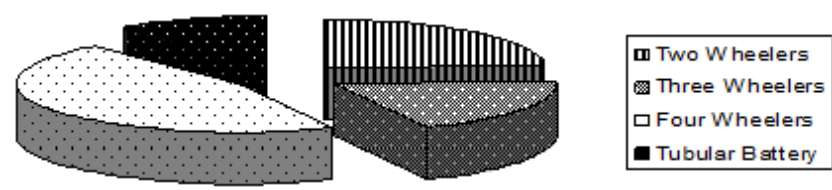

Figure 3. Type of batteries moving fast in the market as per respondents' claim.
Table 8. Problems faced by the dealers

\begin{tabular}{|c|c|c|}
\hline Problems Faced & No. of Respondents & Percentage \\
\hline Yes & 109 & 54.5 \\
\hline No & 91 & 45.5 \\
\hline Total & $\mathbf{2 0 0}$ & $\mathbf{1 0 0}$ \\
\hline
\end{tabular}

Table 8 indicates that 54.5 percent of the respondents have faced certain problems in doing battery business, while the remaining 45.5 percent of the respondents have not faced any problem.

It can be perceived from Table 9 that among the six types of problems mentioned by the dealers, the problem of 'Terms and Conditions' was ranked the first with a garret

Table 9. Problems faced by the dealers with ranks

\begin{tabular}{|c|c|c|c|c|c|c|c|c|c|}
\hline Problems & I & II & III & IV & V & VI & Total & Hendry Garret Score & RANK \\
\hline Quality of Service & 12 & 16 & 16 & 11 & 25 & 29 & 109 & 328 & VI \\
\hline Distributors Direct Approach to Customer & 20 & 19 & 19 & 15 & 25 & 11 & 109 & 397 & III \\
\hline Terms \& Conditions & 19 & 20 & 27 & 20 & 12 & 11 & 109 & 417 & I \\
\hline Mode of Payment & 20 & 21 & 20 & 17 & 17 & 14 & 109 & 404 & II \\
\hline Low Commission & 21 & 23 & 8 & 19 & 15 & 23 & 109 & 383 & IV \\
\hline Delay in Delivery & 17 & 10 & 19 & 27 & 15 & 21 & 109 & 360 & V \\
\hline Total & 109 & 109 & 109 & 109 & 109 & 109 & & & \\
\hline
\end{tabular}

score of 417 points. It is followed by 'Mode of Payment' ranking second with a garret score of 404 points. The 'Distributors Direct Approach to Customer' was ranked third with a garret score of 397 points. The problem of 'Low Commission' was ranked fourth with a garret score of 383 points. The 'Delay in Delivery' was ranked fifth with a garret score of 360 points. The 'Quality of Service' was ranked sixth with a garret score of 328 points.

\section{Findings}

The key findings of the study were- a maximum of 41 percent of the respondents are doing the battery business for a period between 2 and 5 years; 37 percent of the respondents took their own decision to do the battery dealership business; a majority of 55 percent of the respondents have come to know about the battery dealership opportunity through advertisements; a majority of 54.5 percent of the respondents opined that their present business performance is good; a majority of
52 percent of the respondents' average sales in a month is between Rs.30000 and Rs.50,000/-; a maximum of 41 percent of the respondents opined that 'Stiff Competition' was the reason for fluctuation in the battery business performance; a maximum of 46 percent of the respondents opined that the four wheeler batteries only were moving fast in the market; and a majority of 54.5 percent of the respondents expressed that they faced certain problems in doing the battery business in which the problem of 'Terms and Conditions' of the company was ranked the first by the respondents.

\section{Suggestions}

- $\quad$ Battery companies must advertise more through pamphlets and television channels to enhance the awareness among the public.

- $\quad$ Experienced sales representatives to be appointed to improve the sales performance in the stiff competitive market, particularly it is high time 
for tubular batteries because, power cuts stimulate opportunities for selling UPS inverter batteries.

- Battery companies should create favourable policies to satisfy and encourage the existing dealers and also attract new dealers.

\section{Conclusion}

It is clear from the study that the present battery dealership business performance is good. However, companies have to create certain policies which reduce the stringent formalities in the business to encourage the dealers and promote the business. Because of the stiff competition it is essential for the battery companies to select the best media for advertisements and appoint some experienced sales representatives to get more orders and retain the market share. Besides, dealers must also provide quick service to the customers to make them satisfy and remain loyal. If these suggestions are carried out, it will be a great reward yielding the growth and prosperity of the battery business.

\section{References}

1. Raymond O.M. "Benchmarking the Performance of the Technical Services Department of an Automotive Battery Company". Social Science Research Network, Vol. 16, pp. 1-30, 2010.

2. Rahim S. "The Cold,Hard Economics of Electric Cars Points to Making them in the U.S.", New York Times, 2010.

3. Hussain N., Bhatti W.A., and Jilani A. "An Empirical Analysis of After Sales Services and Customers Satisfaction". Management and Marketing Challenges for the Knowledge Society, Vol. 6(4), pp. 561-572, 2011.

4. Tim S. The Electric Car Battery-Sustainability in the Supply Chain, SOMO, Amsterdam, 2011, pp. 4-32.

5. Sachin F. "A Comparative Study of Ameron and Exide Batteries in Amravati", [MBA thesis], 2013, pp. 1-67. Available: www.slideshare.net/sachu1107/a-comparative-study-of-ameron-exide-batteries-in-amravati 